\title{
Association Between Intraoperative Computed Tomography Navigation System and Incidence of Surgical Site Infection in Patients with Spinal Surgeries: A Retrospective Analysis
}

\section{GENTARO KUMAGAl ( $\nabla$ gengen722@hotmail.com )}

Hirosaki University Graduate School of Medicine https://orcid.org/0000-0003-0597-6603

\section{Kanichiro Wada}

Hirosaki University Graduate School of Medicine

\section{Sunao Tanaka}

Hirosaki University School of Medicine Graduate School of Medicine: Hirosaki Daigaku Igakubu Daigakuin Igaku Kenkyuka

\section{Toru Asari}

Hirosaki University School of Medicine Graduate School of Medicine: Hirosaki Daigaku Igakubu Daigakuin Igaku Kenkyuka

\section{Yohshiro Nitobe}

Hirosaki University School of Medicine Graduate School of Medicine: Hirosaki Daigaku Igakubu Daigakuin Igaku Kenkyuka

\section{Yasuyuki Ishibashi}

Hirosaki University School of Medicine Graduate School of Medicine: Hirosaki Daigaku Igakubu Daigakuin Igaku Kenkyuka

\section{Research article}

Keywords: Spinal surgery, intraoperative fluoroscopy, intraoperative CT, surgical site infection

Posted Date: August 10th, 2021

DOI: https://doi.org/10.21203/rs.3.rs-754286/v1

License: (c) (i) This work is licensed under a Creative Commons Attribution 4.0 International License. Read Full License

Version of Record: A version of this preprint was published at Journal of Orthopaedic Surgery and Research on January 29th, 2022. See the published version at https://doi.org/10.1186/s13018-022-02936-6. 


\section{Abstract}

Purpose: Although the use of intraoperative computed tomography (CT)-based navigation systems is unlikely to cause intraoperative contamination more than the use of intraoperative fluoroscopy, the association between intraoperative CT/navigation and surgical site infections (SSIs) remains unclear. We investigated the incidence of SSIs and the association between intraoperative CT/navigation and SSIs for spinal surgeries.

Methods: Of the 512 patients who underwent spinal surgery between April 2016 and December 2020, 304 underwent C-arm intraoperative fluoroscopy and/or Medtronic 0-arm intraoperative CT/navigation system. We investigated the incidence of SSIs in patients with four techniques; no intraoperative imaging C-arm only, O-arm only, and both $\mathrm{O}$ - and $\mathrm{C}$-arm used. Multivariate logistic analyses were conducted using the prevalence of SSIs as the dependent variable. The independent variables were age, sex, and potential confounders including preoperative Japanese Orthopaedic Association (JOA) score, use of instrumentation, C-arm and/or O-arm.

Results: The incidence of the SSIs in patients with no imaging, C-arm only, O-arm only, and both modalities used was $1.9 \bigotimes, 7.3 \%, 4.7 \%$, and $8.3 \%$, respectively. There was no significant difference in the incidence of SSIs between the four techniques. Multivariate logistic analyses showed a significant correlation between the prevalence of SSI and JOA scores (odds ratio, $0.878 ; 95 \% \mathrm{Cl}, 0.759-0.990$ ) and use of instrumentation (odds ratio, $6.241 ; 95 \% \mathrm{Cl}, 1.113-$ 34.985), but not use of 0 -arm.

Conclusions: The incidence of the SSIs in patients with only 0-arm used was 4.7\%. Preoperative clinical status and use of instrumentation, but not use of the 0-arm, was associated with SSIs after spinal surgeries.

\section{Background}

Surgical site infections (SSIs) result in increased patient morbidity, mortality, and healthcare costs. The incidence of SSIs in spinal surgery varies widely; a large database showed an incidence of $0.72 \%$ for laminectomy with no risk factors to $8.7 \%$ for refusion of the spine in patients with three risk factors [1]. The etiology of postoperative SSIs is multifactorial and is often related to a combination of preoperative, intraoperative, and postoperative factors. Instrumentation surgery was reported to be a significant risk factor for SSIs [2]. Intraoperative fluoroscopy and computed tomography (CT)-based navigation are routinely used in the operating room for a variety of spinal instrumentation surgeries. Previous studies have shown that the accuracy of pedicle screw placement using C-arm fluoroscopy-based image-guided techniques was higher than that of manual techniques $[3,4]$. Recent studies have shown that intraoperative CT-based guidance improves the accuracy of pedicle screw placement more than does standard fluoroscopy [5, 6]. 3D preoperative planning and navigation also improve bone tumor resection [7] and the gutter position of cervical laminoplasty [8]. Moreover, intraoperative CT-based imaging reduces radiation dose to patients [9]. Whichever imaging systems guide the spinal instrumentation surgeries, the intraoperative fluoroscopy and CT devices need to be kept sterile while imaging with fluoroscopy and CT scanning. Although the intraoperative $\mathrm{CT} /$ navigation system is unlikely to cause intraoperative contamination more than does intraoperative fluoroscopy, the association between intraoperative $\mathrm{CT} /$ navigation and SSIs remains unclear. The study investigated the incidence and associated factors of SSIs after using Medtronic 0-arm CT/navigation system including other potential confounders for spinal surgeries.

\section{Methods}




\section{Patients}

Overall, 526 consecutive patients who underwent spine surgery between April 2016 and December 2020 were enrolled in the study. Patients with preoperative pyogenic spondylitis and septic wound conditions were excluded. Finally, 512 patients (242 men and 270 women) were included (Fig. 1) and a retrospective analysis of their surgeries and outcomes was completed.Diagnoses are presented in Table 1. The mean age was 64.0 years old. Fifty-five patients were treated using C-arm intraoperative fluoroscopy. For 213 patients, intraoperative CT (Medtronic Sofamor Daneck, Memphis, TN, US) and a navigation StealthStation system (Medtronic Sofamor Danek) were used. Thirty-six patients were treated using both the $\mathrm{C}$-arm and $\mathrm{O}$-arm intraoperatively. Two-hundred eight patients were treated without intraoperative imaging. Intraoperative CT and a navigation StealthStation system were used in cases of insertion of a pedicle screw (PS) [10], cervical laminoplasty [8], resection of bone tumor and decompression. In cases of posterior lumbar interbody fusion, a navigation StealthStation system was used for insertion of the pedicle screw after intraoperative CT examination, and C-arm for the lumbar interbody fusion technique. All patients provided written informed consent before assessment. This research report has been approved by the IRB of the authors' affiliated institution. 
Table 1

Diagnosis and surgical information in each technique.

\begin{tabular}{|c|c|c|c|c|}
\hline \multirow[t]{3}{*}{ Diagnosis } & \multicolumn{4}{|c|}{ Intraoperative imaging information } \\
\hline & No imaging & C-arm only & 0-arm only & Both arms \\
\hline & $(n=208)$ & $(n=55)$ & $(n=213)$ & $(n=36)$ \\
\hline \multicolumn{5}{|l|}{ Trauma } \\
\hline Cervical, N (\%) & $1(0.5)$ & $2(3.6)$ & $3(1.4)$ & $0(0)$ \\
\hline Thoracic, lumbar, N (\%) & $3(1.4)$ & $3(5.5)$ & $7(3.3)$ & $0(0)$ \\
\hline \multicolumn{5}{|l|}{ Degenerative disease } \\
\hline Cervical, N (\%) & $38(18.3)$ & $9(16.4)$ & $107(50.2)$ & $2(5.6)$ \\
\hline Thoracic and lumbar, $\mathrm{N}(\%)$ & $95(45.7)$ & $19(34.5)$ & $13(6.1)$ & $31(86.1)$ \\
\hline Spinal cord tumor, $\mathrm{N}(\%)$ & $52(25)$ & $1(1.8)$ & $7(3.3)$ & $0(0)$ \\
\hline Spinal deformity, N (\%) & $6(2.9)$ & $17(30.9)$ & $64(30.0)$ & 3 \\
\hline RA, N (\%) & $1(0.5)$ & $1(1.8)$ & $7(3.3)$ & $0(0)$ \\
\hline DSA, N (\%) & $0(0)$ & $0(0)$ & $3(1.4)$ & $0(0)$ \\
\hline Metastatic disease, N (\%) & $1(0.5)$ & $0(0)$ & $2(0.9)$ & $0(0)$ \\
\hline Others, N (\%) & $11(5.3)$ & $3(5.5)$ & $0(0)$ & $0(0)$ \\
\hline Instrumentation, $\mathrm{N}(\%)$ & $5(2.4)$ & $51(92.7)$ & $134(62.9)$ & $36(100)$ \\
\hline Posterior surgery, N (\%) & $208(100)$ & $54(98.2)$ & $210(98.6)$ & $34(94.4)$ \\
\hline \multirow[t]{2}{*}{ Number of surgical levels ${ }^{a}$} & 2.00 & 4.00 & 5.00 & 2.00 \\
\hline & $(1.00-3.00)$ & $(1.00-7.00)$ & $(4.00-8.00)$ & $(1.00-3.00)$ \\
\hline \multirow[t]{2}{*}{ Duration of surgery ${ }^{a}$} & 176.50 & 266.00 & 262.00 & 269.50 \\
\hline & $(123.00-257.00)$ & $(198.00-352.00)$ & $(181.50-366.00)$ & $(225.50-373.20)$ \\
\hline \multirow[t]{2}{*}{ Blood loss $(\mathrm{mL})^{a}$} & 95.00 & 350.00 & 250.00 & 240.00 \\
\hline & $(30.00-217.50$ & $(150.00-810.00)$ & $(80.00-580.00)$ & $(122.25-560.00)$ \\
\hline
\end{tabular}

RA: rheumatoid arthritis, DSA: destructive spondyloarthropathy, ${ }^{a}$ Values are presented as median value and interquatile (IQR).

\section{Protocol for the prevention of SSIs}

Peri-operative management for the prevention of SSIs was performed as previously described [11]. Patients who were smokers were instructed to cease smoking for $>4$ weeks before surgery. Patients with diabetes and 
hemoglobin A1c levels of $>7 \%$ underwent glycemic control before surgery. The blood glucose levels of patients over the age of 60 years were controlled, on a sliding scale, for 1-2 weeks after surgery until blood glucose levels were normal. Prophylactic antibiotics were administered via intravenous drip infusion only during the preoperative and intraoperative periods in all consecutive spine surgeries. Cefazolin (based on body weight) was administered as the first choice unless the patient had a history of significant allergies, such as anaphylactic shock, systemic skin eruption, or toxic liver dysfunction. If necessary, the skin hair in the surgical area was removed with clippers in the operating room before surgery. Preoperative antibiotics were administered within 30 mins before skin incision. The surface of the surgical site was cleaned using chlorhexidine in the preoperative period and was immediately coated with iodine drape. Glucodine was used as an additional skin preparation solution from June 2018. Intraoperatively, an additional dose of antibiotics was administered every four hours. If the operation was completed within 4 hours, no additional antimicrobial agent was administered. The surgical site was irrigated using saline solution only as often as possible during the surgery, and a large amount of saline solution was used before closing the surgical site. In the postoperative period, the surgical site was managed with continuous negative pressure suction drainage until 48 hours after surgery.

The identification of an SI involves the interpretation of clinical and laboratory findings. Clinical signs included purulent exudate, surrounding erythema, and wound fluctuance. Laboratory data included prolonged elevation in the values of white blood cells, C-reactive protein, and erythrocyte sedimentation rate. Superficial SSIs involve only the skin or subcutaneous tissue of the incision. Deep SSIs involve the fascia and muscle layers of the incision. An SSI was defined as infection occurring within 30 days after the operation if no implant was left in place, or within one year if the implant was in place and the infection appeared to be related to the surgery. Cefazolin was administered immediately as the first choice if the patient had an SSI. In patients with SSIs, if the bacteria were not sensitive to cefazolin, sensitive antibiotics were administered. All patients could be assessed for any additional SSIs that occurred within one year.

\section{Sterile drape}

All patients were positioned prone on a radiolucent Jackson spinal table (Mizuho OSI, Union City, CA, USA). For patients with whom the C-arm was used, it was fitted with a sterile drape by scrub doctors (Fig. 2A), and the standard aseptic technique was maintained throughout the surgery by the radiology technician operating the $\mathrm{C}$-arm (Fig. 2B). For patients with whom the O-arm was used, the surgical area was covered with sterile drapes while scanning with the O-arm (Fig. 2C). After scanning, surgeons performed the surgical procedure using a navigation system (Fig. 2D).

\section{Evaluation of clinical outcomes}

The severity of clinical symptoms was evaluated using the Japanese Orthopaedic Association (JOA) score to assess cervical myelopathy prior to surgery in each group. This scale consists of six domain scores (motor dysfunction in the upper extremities, motor dysfunction in the lower extremities, sensory function in the upper extremities, sensory function in the trunk, sensory function in the lower extremities, and bladder function) scaled from 0 to 4, 4, 2, 2, 2, and 3, respectively, with a minimum total score of 0 and a maximum total score of 17.

\section{Statistical analyses}

SPSS version 24 (SPSS Inc., Chicago, IL, USA) was used for data input and statistical calculations. The median and interquartile range (IQR) were calculated for continuous variables. The percentage and $95 \%$ confidence interval (Cl) were calculated for categorical variables. The Mann-Whitney U test and chi-square test were used to compare the 
characteristics between males and females. We also compared the conditions with and without SSI for potential risk factors using the Mann-Whitney $U$ test and chi-square test, respectively. The potential risk factors included age, sex, body mass index (BMI), obesity (BMI > 25), presence of hypertension and diabetes, steroid use, smoking, American Society of Anesthesiologists physical status (ASA-PS) of $\geq 3$, JOA score, duration of surgery, and blood loss as known risk factors of SSIs [12]. Independent risk factors for SSIs were identified from multivariate logistic regression analyses, conducted using the prevalence of SSI as the dependent variable in each group. Independent variables with age, sex, BMI, C-arm and/or O-arm, and potential confounders which had a P-value of $<0.05$ in the univariate analysis, were eligible for inclusion in the multivariate models. A P-value of $<0.05$ was considered statistically significant.

\section{Results}

Diagnosis and surgical information in each technique

Table 1 shows diagnosis and surgical information in each technique. The most common diagnosis in patients who required no imaging, $\mathrm{C}$-arm only, or both $\mathrm{C}$-arm and $\mathrm{O}$-arm imaging was degenerative disease in the thoracic and lumbar spine $(45.7 \%, 34.5 \%$, and $86.1 \%$, respectively). The most common diagnosis in patients with only 0-arm imaging was degenerative disease in the cervical spine (50.2\%). The prevalence of instrumentation surgery was low in patients not requiring imaging (2.4\%) and was high in patients imaged with the C-arm and/or 0 -arm (92.7\% and $62.9 \%$ ). The number of surgical levels in patients imaged using only the O-arm was the highest among all techniques. The duration of surgery was lowest in patients for whom intraoperative imaging was not used. Blood loss was highest in patients imaged with the C-arm only.

\section{Characteristics of patients in each gender}

Table 2 shows the patients' characteristics related to age, BMI, obesity, medical history, smoking, steroid use, ASA$P S \geq 3$, and JOA score for each sex. The BMI in males was significantly higher than that in females $(P=0.027)$. The prevalence of hypertension and diabetes, and habit of smoking in males was significantly higher than that in females respectively $(P=0.009,0.003$, and 0.005). No significant differences were found for age, the prevalence of hyperlipidemia and chronic renal failure, steroid use, ASA-PS $\geq 3$, and JOA score. 
Table 2

Characteristics of patients in each gender

\begin{tabular}{|c|c|c|c|c|}
\hline & All $(n=512)$ & Male $(n=242)$ & Female $(n=210)$ & $P$ value ${ }^{b}$ \\
\hline \multirow[t]{2}{*}{$\mathrm{Age}^{\mathrm{a}}$, years } & 64.00 & 64.00 & 63.0 & 0.707 \\
\hline & $(46.5-73.0)$ & $(51.0-72.0)$ & $(31.5-72.0)$ & \\
\hline \multirow[t]{2}{*}{$\mathrm{BMI}^{\mathrm{a}}, \mathrm{kg} / \mathrm{m}^{2}$} & 23.87 & 24.40 & 22.98 & \multirow[t]{2}{*}{$0.027^{\star}$} \\
\hline & $(20.73-27.15)$ & $(21.58-27.00)$ & $(19.83-27.15)$ & \\
\hline Obesity, N (\%) & $210(46.5)$ & $114(47.1)$ & $96(35.6)$ & $0.009^{\#}$ \\
\hline Hypertension, N (\%) & $177(39.2)$ & $100(41.3)$ & $77(28.5)$ & $0.003^{\#}$ \\
\hline Diabetes, N (\%) & $102(22.6)$ & $62(25.6)$ & $40(14.8)$ & $0.003^{\#}$ \\
\hline Hyperlipidemia, N (\%) & $28(6.2)$ & $17(7.0)$ & $11(4.1)$ & 0.174 \\
\hline Chronic renal failure, N (\%) & $25(5.5)$ & $16(6.6)$ & $9(3.3)$ & 0.101 \\
\hline Steroid use, N (\%) & $18(4.0)$ & $6(2.4)$ & $12(4.4)$ & 0.337 \\
\hline Smoking, N (\%) & $27(6.0)$ & $20(8.3)$ & $7(2.6)$ & $0.005^{\#}$ \\
\hline ASA-PS $\geq 3, N(\%)$ & $150(33.2)$ & $80(33.1)$ & $70(25.9)$ & 0.081 \\
\hline \multirow[t]{2}{*}{ JOA score ${ }^{a}$} & 13.5 & 13.5 & 14.0 & \multirow[t]{2}{*}{0.264} \\
\hline & $(11.0-16.0)$ & $(10.0-15.0)$ & $(11.5-17.0)$ & \\
\hline
\end{tabular}

Incidence of SSIs and associated factors

The incidence of SSIs in all patients was $4.1 \%$ (21 cases) (Fig. 1). The incidence of the SSls without imaging, or with C-arm only, O-arm only, and both C- and O-arm was $1.9 \%, 7.3 \%, 4.7 \%$, and $8.3 \%$, respectively (Fig. 1). There was no significant difference in the incidence of SSIs between the four techniques $(P=0.125)$.

Table 3 shows cases of SSIs in each technique. There was one case of superficial SSI and two cases of deep SSI in patients for whom imaging was not used. There were four cases of superficial SSI in patients imaged only using the $\mathrm{C}$-arm. There were three cases of superficial SSI and seven cases of deep SSI in patients imaged only with the 0arm. There were three cases of superficial SSI in patients imaged with both modalities.. Patients with superficial SSIs were treated only with antibiotics. Patients with deep SSIs were treated using surgical intervention and antibiotics without implant removal. Causative bacteria of SSIs were methicillin-sensitive coagulase-negative Staphylococci (MSCNS) and methicillin-resistant coagulase-negative Staphylococci (MRCNS) in four cases, methicillin-sensitive Staphylococcus aureus (MSSA) in two cases, Propionibacterium acnes, Enterobacter cloacae and Enterococcus faecalis in one case each. No bacteria were cultured in five cases, although clinical signs appeared. 
Table 3

Cases of SSIs in each techniques

\begin{tabular}{|c|c|c|c|c|c|c|}
\hline $\begin{array}{l}\text { Age (years), } \\
\text { gender }\end{array}$ & Comorbidities & Diagnosis & $\begin{array}{l}\text { Surgical } \\
\text { methods } \\
\text { /Instrumentation }\end{array}$ & $\begin{array}{l}\text { Type } \\
\text { of } \\
\text { SSI* }\end{array}$ & SSI bacteria & $\begin{array}{l}\text { Additional } \\
\text { surgery }\end{array}$ \\
\hline \multicolumn{7}{|c|}{$\begin{array}{l}\text { No } \\
\text { intraoperative } \\
\text { imaging }\end{array}$} \\
\hline 84 , female & None & $\mathrm{LDH}$ & Herniotomy / No & $S$ & N. D. & No \\
\hline 51 , male & Psoriasis & OPLL & $\begin{array}{l}\text { Cervical } \\
\text { laminoplasty/ } \\
\text { No }\end{array}$ & $\mathrm{D}$ & $\begin{array}{l}\text { Enterobacter } \\
\text { cloacae }\end{array}$ & Yes \\
\hline 76 , male & $\begin{array}{l}\text { Hypertension, } \\
\text { malignant } \\
\text { lymphoma }\end{array}$ & LSS & $\begin{array}{l}\text { Laminectomy / } \\
\text { No }\end{array}$ & $\mathrm{D}$ & $\begin{array}{l}\text { Enterococcus } \\
\text { faecalis }\end{array}$ & Yes \\
\hline \multicolumn{7}{|l|}{ C-arm only } \\
\hline 56 , male & $\begin{array}{l}\text { Athetoid } \\
\text { cerebral palsy }\end{array}$ & CSM & $\begin{array}{l}\text { Posterior fusion/ } \\
\text { Yes }\end{array}$ & $S$ & MSSA & No- \\
\hline 66 , female & $\begin{array}{l}\text { Collagen } \\
\text { disease } \\
\text { (steroid) }\end{array}$ & Trauma & $\begin{array}{l}\text { Posterior fusion/ } \\
\text { Yes }\end{array}$ & $S$ & $\begin{array}{l}\text { MSCNS } \\
\text { MSSA }\end{array}$ & No- \\
\hline 80 , male & Cancer & LSS & $\begin{array}{l}\text { Posterior fusion/ } \\
\text { Yes }\end{array}$ & $S$ & N. D. & No- \\
\hline 78, male & $\begin{array}{l}\text { Hypertension, } \\
\text { diabetes, } \\
\text { stroke }\end{array}$ & CSM & $\begin{array}{l}\text { Posterior fusion/ } \\
\text { Yes }\end{array}$ & $S$ & N. D. & No- \\
\hline \multicolumn{7}{|l|}{ O-arm only } \\
\hline 65 , male & $\begin{array}{l}\text { Hypertension, } \\
\text { diabetes, } \\
\text { stroke }\end{array}$ & CSM & $\begin{array}{l}\text { Posterior fusion/ } \\
\text { Yes }\end{array}$ & $S$ & N. D. & No- \\
\hline 13 , male & $\begin{array}{l}\text { Mental } \\
\text { retardation }\end{array}$ & Scoliosis & $\begin{array}{l}\text { Posterior fusion/ } \\
\text { Yes }\end{array}$ & $S$ & N. D. & No- \\
\hline 62 , male & Cirrhosis & CSM & $\begin{array}{l}\text { Posterior } \\
\text { decompression/ } \\
\text { No }\end{array}$ & $S$ & $\begin{array}{l}\text { Propionibacterium } \\
\text { acnes }\end{array}$ & No \\
\hline 72 , female & RA & $\begin{array}{l}\text { Atlantoaxial } \\
\text { subluxation }\end{array}$ & $\begin{array}{l}\text { Posterior fusion/ } \\
\text { Yes }\end{array}$ & $\mathrm{D}$ & MSCNS & Yes \\
\hline 48 , female & $\begin{array}{l}\text { Athetoid } \\
\text { cerebral palsy }\end{array}$ & CSM & $\begin{array}{l}\text { Posterior fusion/ } \\
\text { Yes }\end{array}$ & $\mathrm{D}$ & MSCNS & Yes \\
\hline 66 , male & OPLL & $\begin{array}{l}\text { T12 burst } \\
\text { fracture }\end{array}$ & $\begin{array}{l}\text { Posterior fusion/ } \\
\text { Yes }\end{array}$ & $\mathrm{D}$ & MRCNS & Yes \\
\hline
\end{tabular}

SSI, surgical site infection; CSM, cervical spondylotic myelopathy; LSS, Lumbar disc herniation; LDH, lumbar spinal stenosis; OPLL, ossification of posterior longitudinal ligament; MSCNS, methicillin-sensitive coagulasenegative staphylococci; MSSA, methicillin-sensitive Staphylococcus aureuS; N. D., not detected; *Type of SSI: S, superficial; D, deep SSI. 


\begin{tabular}{|c|c|c|c|c|c|c|}
\hline $\begin{array}{l}\text { Age (years), } \\
\text { gender }\end{array}$ & Comorbidities & Diagnosis & $\begin{array}{l}\text { Surgical } \\
\text { methods } \\
\text { /Instrumentation }\end{array}$ & $\begin{array}{l}\text { Type } \\
\text { of } \\
\text { SSI* }\end{array}$ & SSI bacteria & $\begin{array}{l}\text { Additional } \\
\text { surgery }\end{array}$ \\
\hline 75 , female & Cancer & $\begin{array}{l}\text { Pseudotumor } \\
\text { of } \mathrm{C} 1\end{array}$ & $\begin{array}{l}\text { Posterior fusion/ } \\
\text { Yes }\end{array}$ & $\mathrm{D}$ & MRCNS & Yes \\
\hline 43 , female & Obesity & OPLL & $\begin{array}{l}\text { Posterior fusion/ } \\
\text { Yes }\end{array}$ & $\mathrm{D}$ & MSCNS & Yes \\
\hline 40, male & - & $\begin{array}{l}\text { Tumor of } \\
\text { thoracic } \\
\text { spine }\end{array}$ & $\begin{array}{l}\text { Posterior fusion/ } \\
\text { Yes }\end{array}$ & $\mathrm{D}$ & $\begin{array}{l}\text { Propionibacterium } \\
\text { acnes }\end{array}$ & Yes \\
\hline 75 , female & RA & $\begin{array}{l}\text { Atlantoaxial } \\
\text { subluxation }\end{array}$ & $\begin{array}{l}\text { Posterior fusion/ } \\
\text { Yes }\end{array}$ & $\mathrm{D}$ & MRSA & Yes \\
\hline \multicolumn{7}{|l|}{$\begin{array}{l}\text { Both O- and } \\
\text { C-arm used }\end{array}$} \\
\hline 69, female & $\begin{array}{l}\text { Chronic renal } \\
\text { failure }\end{array}$ & LSS & $\begin{array}{l}\text { Posterior fusion/ } \\
\text { Yes }\end{array}$ & $S$ & MRCNS & No \\
\hline 88 , female & Hypertension & Trauma & $\begin{array}{l}\text { Posterior fusion/ } \\
\text { Yes }\end{array}$ & $S$ & N. D. & No- \\
\hline 52 , female & $\begin{array}{l}\text { Hypertension, } \\
\text { diabetes, } \\
\text { stroke, } \\
\text { asthma }\end{array}$ & LSS & $\begin{array}{l}\text { Posterior fusion/ } \\
\text { Yes }\end{array}$ & $S$ & MRCNS & No \\
\hline \multicolumn{7}{|c|}{$\begin{array}{l}\text { SSI, surgical site infection; CSM, cervical spondylotic myelopathy; LSS, Lumbar disc herniation; LDH, lumbar } \\
\text { spinal stenosis; OPLL, ossification of posterior longitudinal ligament; MSCNS, methicillin-sensitive coagulase- } \\
\text { negative staphylococci; MSSA, methicillin-sensitive Staphylococcus aureuS; N. D., not detected; *Type of SSI: S, } \\
\text { superficial; D, deep SSI. }\end{array}$} \\
\hline
\end{tabular}

Table 4 shows univariate and multivariate predictors of SSIs in patients after spinal surgeries. The prevalence of steroid use and ASA-PS $\geq 3$ in patients with SSI was significantly higher than that in patients with no SSI $(P=0.003$ and 0.026), respectively (Table 4). The preoperative JOA score was significantly lower in patients with SSI than in patients without SSI $(P=0.041)$ (Table 4). Multivariate logistic analyses showed a significant correlation between the prevalence of SSI and JOA scores (odds ratio, 0.878; 95\% confidence interval, 0.759-0.990) and use of instrumentation (odds ratio, 6.241; 95\% confidence interval, 1.113-34.985), but not when the 0-arm was used (Table 4). 
Table 4

Univariate and multivariate predictors of SSI in patients after spinal surgeries

\begin{tabular}{|c|c|c|c|c|c|c|}
\hline \multirow[t]{2}{*}{ Variables } & \multirow{2}{*}{$\begin{array}{l}\text { Patients with } \\
\text { SSI } \\
(n=21)\end{array}$} & \multirow{2}{*}{$\begin{array}{l}\text { Patients without } \\
\text { SSI } \\
(n=491)\end{array}$} & \multirow{2}{*}{$\begin{array}{l}P \\
\text { value }^{\mathrm{b}}\end{array}$} & \multicolumn{3}{|c|}{ Multivariate analysis* } \\
\hline & & & & OR & $95 \% \mathrm{Cl}$ & $\begin{array}{l}P \\
\text { value }\end{array}$ \\
\hline \multirow[t]{2}{*}{ Age, years } & 66.00 & 64.00 & \multirow[t]{2}{*}{0.482} & \multirow[t]{2}{*}{1.018} & \multirow{2}{*}{$\begin{array}{l}0.987- \\
1.051\end{array}$} & \multirow[t]{2}{*}{0.260} \\
\hline & $(54.00-75.50)$ & $(46.00-73.00)$ & & & & \\
\hline Female sex & 10 & 260 & 0.661 & 0.987 & $\begin{array}{l}0.381- \\
2.559\end{array}$ & 0.979 \\
\hline \multirow[t]{2}{*}{$\mathrm{BMI}^{\mathrm{a}}, \mathrm{kg} / \mathrm{m}^{2}$} & 25.00 & 23.70 & \multirow[t]{2}{*}{0.373} & \multirow[t]{2}{*}{1.042} & \multirow{2}{*}{$\begin{array}{l}0.947- \\
1.145\end{array}$} & \multirow[t]{2}{*}{0.400} \\
\hline & $(21.72-30.23)$ & $(27.70-27.10)$ & & & & \\
\hline Obesity, & 10 & 200 & 0.651 & - & - & - \\
\hline Hypertension, N (\%) & 7 & 170 & 1.000 & - & - & - \\
\hline Diabetes, N (\%) & 3 & 99 & 0.780 & - & - & - \\
\hline Hyperlipidemia & 1 & 27 & 1.000 & - & - & - \\
\hline Chronic renal failure & 1 & 24 & 1.000 & - & - & - \\
\hline Steroid use & 3 & 15 & $0.033^{\#}$ & 3.104 & $\begin{array}{l}0.677- \\
14.227\end{array}$ & 0.145 \\
\hline Smoking & 0 & 27 & 0.618 & - & - & - \\
\hline ASA-PS $\geq 3$ & 11 & 139 & $0.026^{\#}$ & 1.878 & $\begin{array}{l}0.702- \\
5.025\end{array}$ & 0.209 \\
\hline \multirow[t]{2}{*}{ JOA score ${ }^{a}$} & 11.50 & 13.20 & \multirow[t]{2}{*}{$0.041^{*}$} & \multirow[t]{2}{*}{0.878} & \multirow{2}{*}{$\begin{array}{l}0.779- \\
0.990\end{array}$} & \multirow[t]{2}{*}{0.034} \\
\hline & $(7.00-13.50)$ & $(11.00-16.00)$ & & & & \\
\hline C-arm use & 4 & 52 & 0.271 & 0.921 & $\begin{array}{l}0.107- \\
7.921\end{array}$ & 0.940 \\
\hline O-arm use & 10 & 204 & 0.654 & 0.631 & $\begin{array}{l}0.102- \\
3.886\end{array}$ & 0.619 \\
\hline Both use & 3 & 33 & 0.177 & 0.628 & $\begin{array}{l}0.064- \\
6.136\end{array}$ & 0.619 \\
\hline Instrumentation & 16 & 211 & $0.003^{\#}$ & 6.241 & $\begin{array}{l}1.113- \\
34.985\end{array}$ & 0.037 \\
\hline \multirow{2}{*}{$\begin{array}{l}\text { Number of surgical } \\
\text { levels }^{a}\end{array}$} & 4.00 & 4.00 & \multirow[t]{2}{*}{0.274} & \multirow[t]{2}{*}{-} & \multirow[t]{2}{*}{-} & \multirow[t]{2}{*}{-} \\
\hline & $(2.00-5.00)$ & $(2.00-5.00)$ & & & & \\
\hline
\end{tabular}

SSI, surgical site infection; OR, odds ratio; BMI, body mass index; ASA-PS, American Society of Anesthesiologists Physical Status; JOA, Japanese Orthopaedic Association., bignificant differences $(P<.05)$ between values for patients with SSI and without SSI were calculated by *Mann-Whitney U or \#Chisquare test. 


\begin{tabular}{|c|c|c|c|c|c|c|}
\hline \multirow[t]{2}{*}{ Variables } & \multirow{2}{*}{$\begin{array}{l}\text { Patients with } \\
\text { SSI } \\
(n=21)\end{array}$} & \multirow{2}{*}{$\begin{array}{l}\text { Patients without } \\
\text { SSI } \\
(n=491)\end{array}$} & \multirow{2}{*}{$\begin{array}{l}P \\
\text { value }^{\mathrm{b}}\end{array}$} & \multicolumn{3}{|c|}{ Multivariate analysis* } \\
\hline & & & & $\mathrm{OR}$ & $95 \% \mathrm{Cl}$ & $\begin{array}{l}P \\
\text { value }\end{array}$ \\
\hline \multirow[t]{2}{*}{ Duration of Surgery, min } & 266.00 & 217.00 & 0.123 & - & - & - \\
\hline & $\begin{array}{l}(186.50- \\
367.50)\end{array}$ & $(154.25-321.75)$ & & & & \\
\hline \multirow[t]{2}{*}{ Blood loss, ml } & 330.00 & 150.00 & 0.260 & - & - & - \\
\hline & $(90.00-725.00)$ & $(50.00-400.00)$ & & & & \\
\hline
\end{tabular}

\section{Discussion}

To the best of our knowledge, this is the first study to clarify the incidence of SSIs after using the intraoperative 0arm/navigation system for spinal surgeries. Preoperative clinical status and use of instrumentation, but not intraoperative CT/navigation, was associated with SSIs after spinal surgeries.

The incidence of SSIs in spinal surgery varies widely, and a large database indicated an incidence of $0.72 \%$ for laminectomy with no risk factors to $8.7 \%$ for refusion of the spine in patients with three risk factors [1]. In the Medicare population, Kurtz et al. reported the rate of SSIs in instrumented patients as $8.5 \%$ in primary fusions and $12.2 \%$ in refusions [13]. In our SSI prevention protocol, the incidence of SSIs when either the C-arm, O-arm, or both were used togetheter were $7.3 \%, 4.7 \%$, and $8.3 \%$, respectively, and are similar to those reported in previous studies of instrumented spinal surgeries [1].

Several studies have identified risk factors for SSIs in spine surgery. A recent meta-analysis reported 13 risk factors that were statistically significant [14]. Those that were modifiable through patient selection and optimization included ASA-PS of $>2$ (OR, 2.27; 95\% Cl: 1.5-3.42), diabetes (OR, 2.04; 95\% Cl: 1.69-2.46), obesity (OR, 2.21; $95 \%$ $\mathrm{Cl}$ 1.55-2.93), BMI (OR, $0.25 ; 95 \% \mathrm{Cl}: 0.1-0.4)$, revision surgery (OR, 1.85; $95 \% \mathrm{Cl}: 1.46-2.34)$, smoking (OR, 1.17; $95 \% \mathrm{Cl}: 1.03-1.32)$, urinary tract infection (OR, 3.19; $95 \% \mathrm{Cl}$ : 1.68-6.06), hypertension (OR, 1.67; 95\% Cl: 1.26-2.22), CSF leak (OR, 3.22; 95\% Cl: 1.07-9.67), and dural tear (OR, 3.01; $95 \%$ Cl: 1.6-5.66). Although age was not a significant factor, other studies have reported that older age was a significant risk factor independent of comorbidities. Additionally, patients with diabetes have been shown to have worse patient-reported outcomes for up to two years after spine surgery [15]. In our study, patients with SSIs did not have diabetes, and diabetes was not a risk factor for SSI. These results raise the real possibility that stringent glycemic control may mitigate the risk of SSIs. Our study suggested the severity of neurological findings as JOA score were associated with SSIs. Therefore, we need to pay attention to prevent SSIs in patients with severe cervical spondylotic myelopathy and spinal cord injury. Moreover, a systematic review showed that 2 of the 6 studies found a statistically significant association between instrumentation and postoperative SSI [12]. Therefore, the author concluded they could not rule out a possible association. Further analysis of the role instrumentation as independent risk factors for SSIs was beyond the scope of this initial study and will be explored in the future.

A common source of contamination in spine surgery is the use of a "C-arm" for intraoperative fluoroscopy. To maintain sterility, a sterile drape is placed over the portion of the machine that will be in close contact with the 
operating field. Biswas performed a prospective study to assess the sterility of C-arms at the end of 25 spine surgery cases [18]. Five areas of the C-arm were cultured immediately after drape application and at the end of surgery. One location (4\%) was culture positive after immediate draping. All drapes were cultured at the end of the procedure, and all areas were contaminated, with the upper areas of the C-arm being most frequently contaminated. The authors recommend that these regions need to be considered nonsterile. The use of intraoperative CT and navigation systems is unlikely to cause intraoperative contamination more than the use of intraoperative fluoroscopy. Since there was no significant difference in the incidence of SSIs between the use of C-arm and O-arm, SSIs may be more associated with factors other than with the surgical environment.

Our study has several limitations. First, in our protocol, surgical methods, type of instrumentation, surgeons, and the number of operating room staff were different between all the techniques. Second, the cultures of the C-arm and Oarm equipment were not examined before and after surgery. Therefore, the mechanisms underlying development of the SSIs remain unclear. Third, the reason for many deep SSI cases (70\%) when only is used is unknown. Finally, our sample size for the $\mathrm{C}$-arm group and the group where both images were used was too small.

\section{Conclusions}

The incidence of the SSIs in patients imaged only with the 0-arm was $4.7 \%$. Preoperative clinical status and use of instrumentation, but not intraoperative fluoroscopy and CT were associated with SSIs after spinal surgeries. This findings could provide clinical information of patients undergoing spinal instrumentation surgery.

\section{Abbreviations}

SSIs, surgical site infections; CT, computed tomography; JOA score, the Japanese Orthopaedic Association score; IQR, interquarile range; $\mathrm{Cl}$, confidence interval; BMI, body mass index; ASA-PS, American Society of Anesthesiologists physical status; MSCNS, methicillin-sensitive coagulase-negative Staphylococci, MRCNS, methicillin-resistant coagulase-negative Staphylococci, MSSA, methicillin-sensitive Staphylococcus aureus

\section{Declarations}

Etics approval and consent to participate: This study was approved by the institutional ethics committee. Approval number is 2019-1038.

Consent to publication: Yes

Competing interests: No

Funding information: None

Author Contributions: Conceived and designed the experiments: GK, KW, and YI. Performed the experiments: GK, WK, ST, TA, and YN. Analyzed the data: GK. Wrote the paper: GK.

Acknowledgements: This study was supported by Dr Toshihiro Tanaka from the Department of Orthopaedic Surgery, Takaoka Seishikai Hospital, Toyama, Japan and Dr Hitoshi Kudo from the Department of Orthopaedic Surgery, Mutsu General Hospital, Aomori, Japan. We would like to thank Editage (www.editage.com) for English language editing. 
Author's information: The data are available on reasonable request from the corresponding author.

\section{References}

1. Edwards JR, Peterson KD, Mu Y, Banerjee S, Allen-Bridson K, Morrell G, Dudeck MA, Pollock DA, Horan TC (2009) National Healthcare Safety Network (NHSN) report: data summary for 2006 through 2008, issued December 2009. Am J Infect Control 37:783-805. doi: 10.1016/j.ajic.2009.10.001

2. de Lissovoy G, Fraeman K, Hutchins V, Murphy D, Song D, Vaughn BB (2009) Surgical site infection: incidence and impact on hospital utilization and treatment costs. Am J Infect Control 37:387-397. doi: 10.1016/j.ajic.2008.12.010

3. Guzey FK, Emel E, Hakan Seyithanoglu M, Serdar Bas N, Ozkan N, Sel B, Aycan A, Alatas I (2006) Accuracy of pedicle screw placement for upper and middle thoracic pathologies without coronal plane spinal deformity using conventional methods. J Spinal Disord Tech 19:436-441. doi: 10.1097/00024720-200608000-00011

4. Hart RA, Hansen BL, Shea M, Hsu F, Anderson GJ (2005) Pedicle screw placement in the thoracic spine: a comparison of image-guided and manual techniques in cadavers. Spine (Phila Pa 1976) 30:E326-331. doi: 10.1097/01.brs.0000166621.98354.1d

5. Mason A, Paulsen R, Babuska JM, Rajpal S, Burneikiene S, Nelson EL, Villavicencio AT (2014) The accuracy of pedicle screw placement using intraoperative image guidance systems. J Neurosurg Spine 20:196-203. doi: 10.3171/2013.11.SPINE13413

6. Santos ER, Ledonio CG, Castro CA, Truong WH, Sembrano JN (2012) The accuracy of intraoperative O-arm images for the assessment of pedicle screw postion. Spine (Phila Pa 1976) 37:E119-125. doi: 10.1097/BRS.0b013e3182257cae

7. Ritacco LE, Milano FE, Farfalli GL, Ayerza MA, Muscolo DL, de Quiros FG, Aponte-Tinao LA (2013) Bone tumor resection: analysis about $3 \mathrm{D}$ preoperative planning and navigation method using a virtual specimen. Stud Health Technol Inform 192:1162

8. Kudo H, Wada K, Kumagai G, Tanaka S, Asari T, Araki R, Takeuchi K, Yokoyama T, Ishibashi Y (2020) Accuracy of the Gutter Position in Cervical Double-door Laminoplasty Using Intraoperative Computed Tomography Navigation and the Factors Associated With C5 Palsy. Clin Spine Surg 33:E553-E558. doi: 10.1097/BSD.0000000000001004

9. Costa F, Dorelli G, Ortolina A, Cardia A, Attuati L, Tomei M, Milani D, Balzarini L, Galbusera F, Morenghi E, Fornari M (2015) Computed tomography-based image-guided system in spinal surgery: state of the art through 10 years of experience. Neurosurgery 11 Suppl 2:59-67; discussion 67-58. doi: 10.1227/NEU.0000000000000587

10. Kudo H, Wada K, Kumagai G, Tanaka S, Asari T, Ishibashi Y (2021) Accuracy of pedicle screw placement by fluoroscopy, a three-dimensional printed model, local electrical conductivity measurement device, and intraoperative computed tomography navigation in scoliosis patients. Eur J Orthop Surg Traumatol 31:563-569. doi: 10.1007/s00590-020-02803-2

11. Numasawa T OA, Wada K, Yamasaki Y, Kumagai G, Yokoyama T, Ueyama K, Toh S, Ishibashi Y (2015)Ispostoperative-antimicrobial-prophylaxis-needed-for-the-management-of-surgical-site-infection-after-spinalinstrumentation surgery? Journal of Spine 4:1000219. doi: 10.4172/21657939.1000219

12. Schuster JM, Rechtine G, Norvell DC, Dettori JR (2010) The influence of perioperative risk factors and therapeutic interventions on infection rates after spine surgery: a systematic review. Spine (Phila Pa 1976) 35:S125-137. doi: 10.1097/BRS.0b013e3181d8342c

Page $13 / 15$ 
13. Kurtz SM, Lau E, Ong KL, Carreon L, Watson H, Albert T, Glassman S (2012) Infection risk for primary and revision instrumented lumbar spine fusion in the Medicare population. J Neurosurg Spine 17:342-347. doi: 10.3171/2012.7.SPINE12203

14. Meng F, Cao J, Meng X (2015) Risk factors for surgical site infections following spinal surgery. J Clin Neurosci 22:1862-1866. doi: 10.1016/j.jocn.2015.03.065

15. Armaghani SJ, Archer KR, Rolfe R, Demaio DN, Devin CJ (2016) Diabetes Is Related to Worse Patient-Reported Outcomes at Two Years Following Spine Surgery. J Bone Joint Surg Am 98:15-22. doi: 10.2106/JBJS.0.00297

16. Garcia Leoni ME, Esclarin De Ruz A (2003) Management of urinary tract infection in patients with spinal cord injuries. Clin Microbiol Infect 9:780-785. doi: 10.1046/j.1469-0691.2003.00643.x

17. Olsen MA, Mayfield J, Lauryssen C, Polish LB, Jones M, Vest J, Fraser VJ (2003) Risk factors for surgical site infection in spinal surgery. J Neurosurg 98:149-155

18. Biswas D, Bible JE, Whang PG, Simpson AK, Grauer JN (2008) Sterility of C-arm fluoroscopy during spinal surgery. Spine (Phila Pa 1976) 33:1913-1917. doi: 10.1097/BRS.0b013e31817bb130

\section{Figures}

Retrospective cohort study undergoing spinal surgery at a single institution: 526 cases

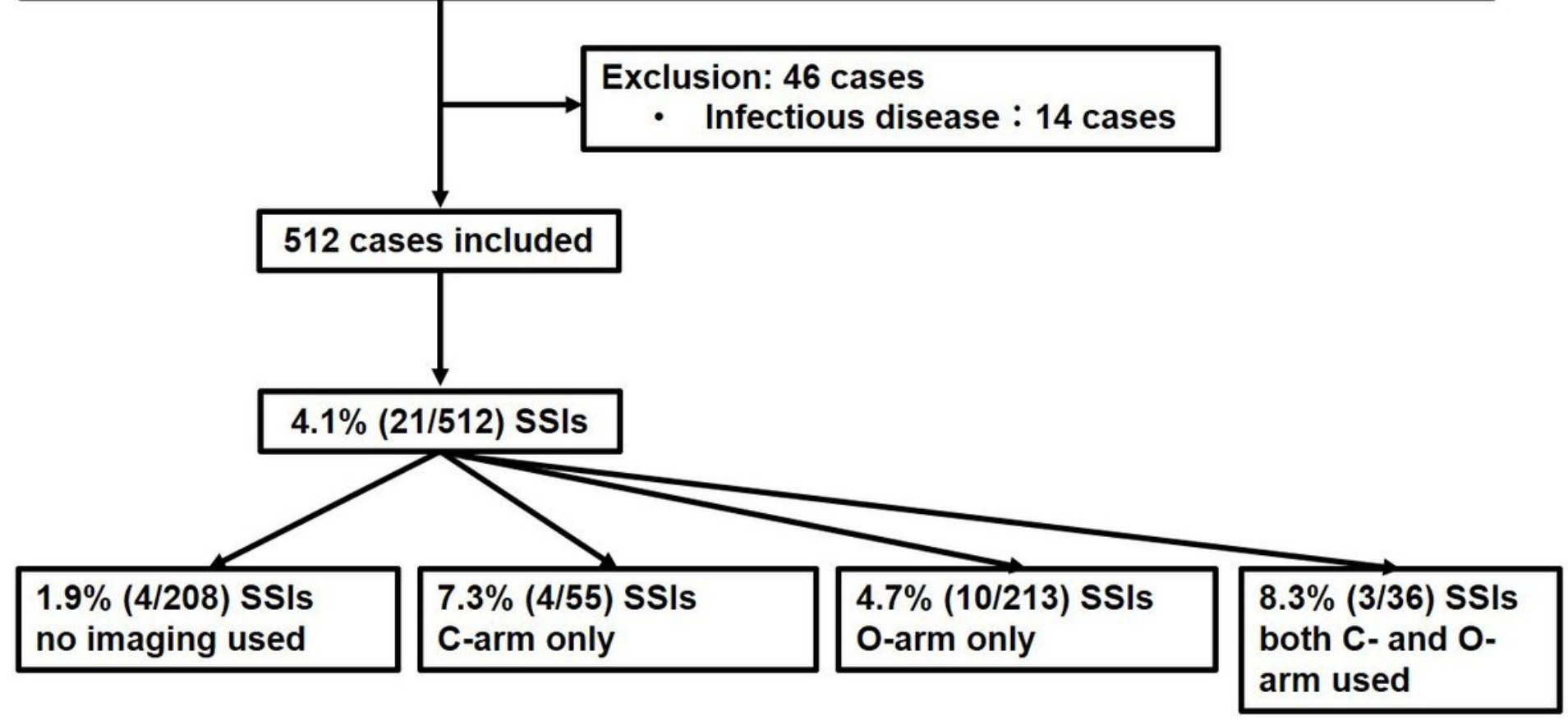

Figure 1

Flow diagram in this study The subjects were 512 patients who underwent posterior spine surgery at our department. The incidence of the SSIs in all patients was $4.1 \%$. The incidence of the SSIs when no imaging, C-arm only, 0 -arm only, or both modalities were used was $1.9 \otimes, 7.3 \%, 4.7 \%$, and $8.3 \%$, respectively. 


\section{Figure 2}
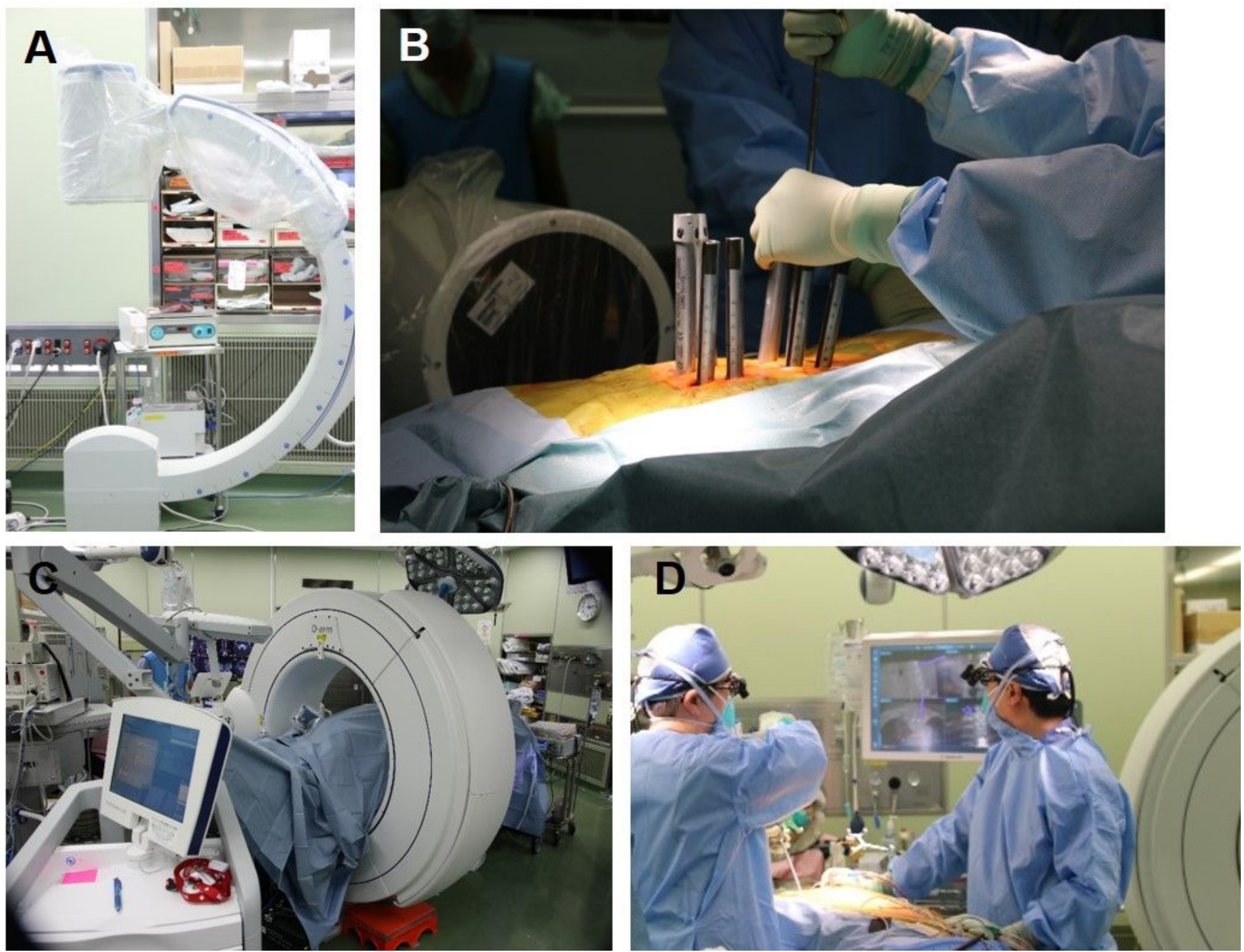

\section{Figure 2}

A sterile procedure of A-arm and O-arm/navigation. C-arm fitted with a sterile drape (A), positioned to acquire AP view and was covered with sterile drapes lateral view (B). The surgical area was covered with sterile drapes while scanning using the 0 -arm (C). Surgeons used navigation system (D) AP, anteroposterior. 